\title{
Website Based E-Module Development on Computer System in Vocational High School
}

\author{
Nesia Yolanda ${ }^{*}$, Fahmi Rizal ${ }^{2}$ \\ 1,2Program Studi Pendidikan Teknologi Kejuruan, Universitas Negeri Padang, Indonesia \\ Jl. Prof. Hamka Kampus UNP Air Tawar Padang \\ *Corresponding Author: nesiayolanda1204@gmail.com
}

\begin{abstract}
INTISARI
Guru sebagai fasilitator harus dapat memberikan fasilitas yang memungkinkan kemudahan belajar mengajar, hal ini tidak sesuai dengan kondisi yang ada dilapangan, guru sudah menggunakan media berbasis teknologi informasi dan komunikasi, namun penggunaan media yaitu powerpoint tersebut masih belum maksimal, belum terdapat video, simulasi dan evaluasi. Selain itu, dalam situasi pandemi ini, proses pembelajaran menjadi kurang efektif, dikarenakan proses pembelajaran tatap muka dibagi menjadi 2 shift. Dalam kondisi seperti ini dituntut adanya media pembelajaran berbasis online. Hal tersebut berdampak pada nilai sistem komputer kelas X jurusan TKJ di SMKN 1 Painan. Metode yang digunakan dalam penelitian ini adalah penelitian Research and Development (R\&D). Model pengembangan yang digunakan adalah pengembangan model 4-D. Model pengembangan 4-D terdiri dari 4 tahap yaitu Define (Pendefinisan), Design (Perancangan), Develop (Pengembangan), dan Disseminate (Penyebaran). Hasil penelitian menunjukkan bahwa: (1) penelitian ini telah menghasilkan sebuah produk e-modul untuk mata pelajaran sistem komputer di SMK Negeri 1 Painan dengan menggunakan domain yaitu https://emodulsiskom.com/smkn1painan/ yang dapat diakses oleh guru maupun siswa dengan komputer, laptop, maupun smartphone yang terhubung dengan internet melalui web browser kapanpun dan dimanapun berada. (2) E-Modul pada mata pelajarann Sistem Komputer yang dikembangkan sudah valid, praktis dan efektif.
\end{abstract}

Kata kunci: Modul Berbasis Website, Sistem Komputer, Efektivitas, Kepraktisan, Validitas.

\begin{abstract}
The problem in this research is that in computer system learning, there is no special media for online learning. During the learning process using teaching materials in the form of power points. The teacher as a facilitator must be able to provide facilities that support teaching and learning, this is not in accordance with existing conditions in the field, the teacher does use information and communication technology-based media, but the use of power point media is still not optimal, there is no video, simulation and evaluation . In addition, during this pandemic situation, the learning process is less effective, because the face-to-face learning process is divided into 2 shifts. In this condition, online-based learning media is demanded. This has an impact on the grade X computer value system of TKJ (computer and network engineering) majors at SMKN 1 Painan. The method used in this research is research and development (R\&D). The development model used is the 4-D model development. The 4-D development model consists of 4 stages, namely Definition, Design, Development and Deployment. The results showed that: (1) this research has produced a website-based learning module product for computer system subjects at SMK Negeri 1 Painan using a domain, namely https://emodulsiskom.com/smkn1painan/ which can be accessed by teachers and students. with a computer, laptop, or smart phone connected to the internet via a web browser whenever and wherever they are. (2) The E-Module on the subject of Computer Systems that was developed is valid, practical and effective.
\end{abstract}

Keywords: Website Based Module, Computer System, Effectiveness, Practicality, Validity. 



\section{INTRODUCTION}

To face the era of the 4.0 revolution, education is needed that is able to form a creative, innovative, and competitive generation[1], [2]. This can be achieved by optimizing the use of technology as an educational tool that is expected to produce outputs that can follow or change over time for the better[3], [4]. One of the supports for the quality of education to face the 4.0 industry revolution is to leverage learning using technology, i.e. blended learning. Blended learning is a learning environment designed by combining face -to -face learning with online learning that aims to improve student learning outcomes[5], [6].

Therefore, the need to support student learning media, namely the use of e-modules. One of the subjects taken was Computer Systems. Computer systems is one of the subjects in SMK, especially in the Computer and Network Engineering Skills Program. In general, the material delivery of these computer systems is divided into two, namely theory and practice. Theoretical material is presented in a conventional way in which the teacher acts as the center of learning, while during the practicum, students are required to be able to recognize and identify hardware directly using the teaching media. Therefore, the need for media as support in the learning process of computer systems [7], [8].

Based on observations on the results of interviews conducted by researchers on 3 August 2020, with the subject teacher of computer system class X TKJ (Computer and Network Engineering) at SMKN 1 Painan. In computer system learning, there is no special online learning media. So far, the learning process uses teaching materials in the form of power point. The media should not be seen as a mere learning aid, it should be seen as a muchneeded educational prerequisite. Teachers as facilitators must be able to provide facilities that enable teaching and learning, this is not suitable for the situation in the field, teachers do use media based on information and communication technology, but the use of media, namely power point, is still not optimal, no video, simulation and assessment [5], [9]. Moreover, in this pandemic situation, the learning process is less effective, because the face -to -face learning process is divided into 2 shifts. In this situation, online -based learning media is demanded. From the above problems, it affects the value of the Class X Computer System of the TKJ (Computer and Network Engineering) in SMKN 1 Painan. Based on observations, the number of students in class $\mathrm{X}$ is 35 people. With a Minimum Completion Criteria (MOH) of 75, a total of 20 students a percentage of $57 \%$ did not meet the $\mathrm{MOH}$. Therefore, more than half of the students still get marks under the MOH. This value is obtained based on the results of the Mid -Semester Examination marks in the 2020/2021 school year in the computer system subject.

Through e-modules, it is hoped to provide alternatives to increase student motivation, especially in the subject of Computer Systems [3]. The site accommodates distance learning, is easy to develop and modify, facilitates assessment, encourages self -directed learning, and the site offers a variety of resources to accurately use, stimulate and enhance learning, including multimedia, hyperlinks, and creating efficient online communication and effective learning effects [4]. Based on the above information, the author's need to contribute in the learning of Computer Systems can be improved, one of which is the development of e-modules in SMKN 1 Painan.

\section{METHOD}

The method used in this research is Research and Development (R\&D). Developmental research methods that are needs analysis can produce specific products, and the effectiveness of these products is tested [10], [11]. The selection of this method is based on the consideration that this type of research is arranged programmatically with a systematic sequence of activities, aiming to produce a product that is in accordance with the problem behind the research and is suitable for research in education[12]. In addition, this method can encourage a continuous process of product / model innovation so that it is expected that models or products will always be found that are always up to date. This research is included in the category of development research because this research produces e-modules. Before conducting research and development, an analysis of product needs or consumer needs is done. The hope is that once the analysis is carried out, the benefits of the developed product can be put to use. The purpose of this research is to develop an e-module product that can be used in the subject of Computer Systems in SMKN 1 Painan. The expansion model is the basis for developing the product to be produced. The development model used is the development of a 4D model. The 4-D expansion model consists of 4 levels, namely Define, Design, Develop, and Disseminate[13][14], [15]. 
1. Define (Defining), the stage with the aim of identifying problems in the field, starting from the field observation stage, analyzing students, to formulating learning concepts.

2. Design (Design), after defining the next stage making a website-based e-module prototype.

3. Develop (Development), after revision of the emodule product, the following stages are carried out:

a. E-module validation test

The validation stage is carried out aimed at assessing the product design. In this case, the data validity results use the Aiken's V validity coefficient, according to [6]. to determine the validity of the e-module can be seen in the table 1.

Table 1. Validity Level Criteria

\begin{tabular}{cll}
\hline No. & Achievement Level & Category \\
\hline 1 & $0,667-1,00$ & Valid \\
2 & $\geq 0,667$ & Invalid \\
\hline
\end{tabular}

b. E-Module Practicality Test

The practicality test was carried out aimed at determining the level of practicality (usability) of the product design. To see the practicality level of the e-module, it can be seen in the following table.

Table 2. Validity Level Criteria

\begin{tabular}{ccc}
\hline No. & Level of attainment $(\%)$ & Category \\
\hline 1 & $81-100$ & Very practical \\
2 & $61-80$ & Practical \\
3 & $41-60$ & Pretty \\
& $21-40$ & practical \\
4 & $0-20$ & Less practical \\
5 & It's not \\
& practical \\
\hline
\end{tabular}

\section{c. Effectiveness Test}

The effectiveness test is carried out after the emodule is declared practical. For the effectiveness of e-modules, an e-module evaluation stage is carried out, with the aim of the e-module being used to improve the quality of student learning outcomes. The technique used in this effectiveness test is by conducting pre-test and post-test.

\begin{tabular}{|c|c|c|}
\hline Pretest & Perlakuan & Postest \\
\hline $\mathrm{O}_{1}$ & $\mathrm{X}$ & $\mathrm{O}_{2}$ \\
\hline
\end{tabular}

From the table above, it shows that 01 is the pretest value (before treatment is carried out), 02 is the Post-test value (after being given treatment). $\mathrm{X}$ is a treatment (the application of the developed e-module). Furthermore, a comparison is made using the Gain Score formula.

$$
\mathrm{g}=\frac{\mathrm{S} \text { post }-\mathrm{S} \text { pre }}{100-\mathrm{S} \text { pre }} 100 \%
$$

The aim of the gain score is to determine the increase in student learning outcomes in terms of differences in learning outcomes. The gain score category can be seen in the table 3 .

Table 3. Gain Score Category

\begin{tabular}{ccc}
\hline No. & Level of attainment $(\%)$ & Category \\
\hline 1 & $\mathrm{~g}>0,70$ & High \\
2 & $0,30<\mathrm{g}<0,69$ & Moderate \\
3 & $\mathrm{~g}<0,29$ & Low \\
\hline
\end{tabular}

4. Disseminate (Spread), After all stages are carried out and the e-module has been declared valid, practical, and effective. Then the distribution of the product was carried out by implementing a website-based e-module in class X majoring in TKJ (Computer and Network Engineering) at SMKN 1 Painan. Website-based e-modules can be implemented by students and teachers in the learning process.

\section{RESULTS AND DISCUSSION}

\section{Definition Stage (Define)}

The defining stage describes how the conditions in the field are related to the learning process of Class X Computer Systems in the Computer and Network Engineering Skills Program at SMK Negeri 1 Painan. At this stage there are 4 things done, namely observation analysis, student analysis, task analysis, and concept analysis, with the following descriptions:

\section{Observation Analysis}

Lesson this computer system is theoretical and practical which requires modules and media for the assistance of students and teachers in carrying out learning, with many abstract theories and practices, it makes it difficult for students to understand the material and takes a lot of time to explain the material in detail. This causes students to not optimally carry out the process existing learning. Meanwhile, the greater student participation in learning can improve students' memory and understanding. In addition, Researchers conducted research during the Covid-19 pandemic situation, where the learning situation at that time was divided into 2 shifts. This causes less effective learning time.Based on the problems that the researcher found, the alternative solution is to use existing 
electronic devices (computers and smart phones) as an introductory medium for the learning module.

2. Student Analysis

Student analysis was carried out before learning in class. The test subjects in this study were class $\mathrm{X}$ students of the TKJ (Computer and Network Engineering) Skills Program at SMK Negeri 6 Padang. The age of class $\mathrm{X}$ vocational students These are in the range of 15 years to 18 years where the class X Vocational School students are entering the developmental stage of adolescence.Based on the analysis of these students, it was made considerations in the development of e-modules on the subject of Computer Systems. Especially in the Logic Gate material. The emodule is developed according to the conditions and characteristics of students. By using this emodule, students can more easily master the material that is presented attractively in the form of a web that can be accessed via computers and smart phones.

3. Task Analysis

In this task analysis, an analysis of the Basic Competencies (KD) that you want to develop to make e-modules is carried out. In this research, what is analyzed is the basic competence Logic Gates studied in class $\mathrm{X}$ in the Computer and Network Engineering expertise program at SMK. Based on the results of KD identification in the syllabus, several learning indicators are described.

4. Concept Analysis

Concept analysis is carried out to identify the main concepts that will be used and to identify supporting concepts that are relevant and related to the material of computer systems in e-module development. The main concept in the subject of Computer Systems is that students can understand the material of logic gates.

5. Formulation of Learning Objectives

The explanation of indicators in the material of Computer Systems, these indicators are learning objectives that are formulated to be achieved to analyze basic, combination and sequential logic relations as well as to assemble basic, combination and sequential logic gate functions. This description is taken into consideration in determining the material and concepts needed in learning computer systems. The results of the curriculum analysis can be used as the basis for designing e-modules in the subject of Computer Systems. Especially in the logic gate material. The e-module is also designed to be used independently by students.

\section{Design Stage (Design)}

1. Preparation of Test Standards

The preparation of this test is based on the basic competencies of logic gates. This test serves as an evaluation tool for students' abilities after the implementation of the e-module. The tests in question are pretest and post test, tests that are arranged in the form of multiple choice objective tests.

\section{Media Selection}

Media selection is carried out to identify appropriate learning media for the presentation of the material presented. The e-module in this study which was designed using the Moodle 3.9 LMS was chosen because Moodle has complete features and is one of the most widely used LMS for learning, Moodle is very supportive for independent learning, Moodle provides features such as chat, forums, assignments, practice questions, a list of absences and can support images, animation and video to become a learning medium, therefore Moodle was chosen for the development of e-modules on computer systems subjects.

3. Format Selection

Format selection in learning media development must design learning content, choosing the format chosen is writing material in the form of media that is presented starting from learning objectives, material descriptions, and evaluation.

4. Initial Design

At this stage, the preparation of the e-module display design framework which includes the initial display, the learning view, the exercise display contains questions to test the students' ability to the material presented in the e-module and the discussion forum view. The results of the e-module display design consist of:

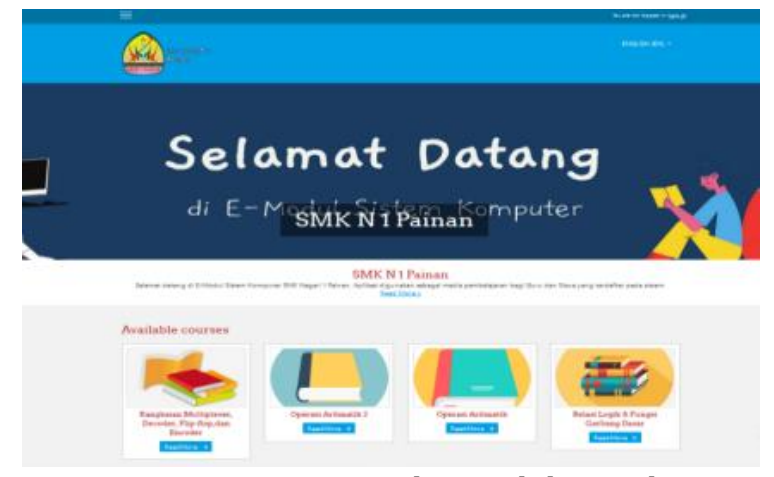

Figure 1. Initial E-Module Display 


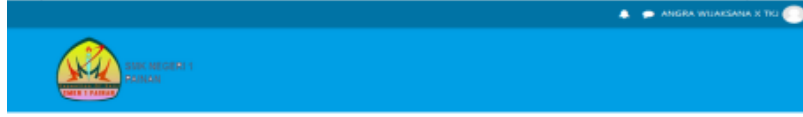

ogik \& Fungsi Gerbang Dasar

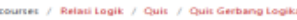

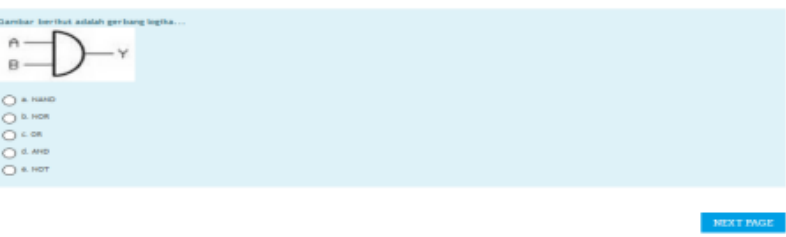

Figure 2. Exercise View

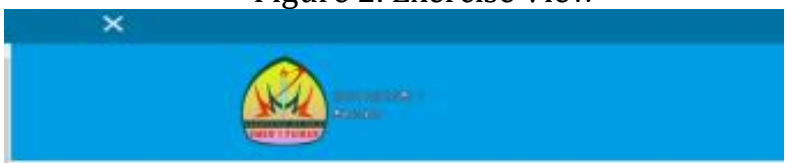

Sistem Bilangan

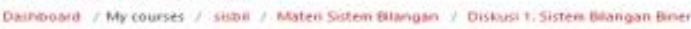

Diskuoi 1. Sistem Bilangan Biner

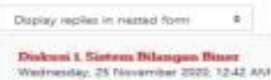

Figure 3. Display of the Discussion Forum

\section{Development Stage (Develop)}

This phase aims to produce a valid, practical and effective e-module. In this development phase, it consists of the validation stage by media and material validators, then the practicality stage by teachers and students and the last stage is the effectiveness test stage for e-modules.

1. E-Module Validation

The results of the validation recapitulation are summarized from the aspects of the learning media that are assessed as shown in table 4 below.

Table 4. Media Validation Results for e-module

\begin{tabular}{llll}
\hline No. & Validator & Assessment & $\begin{array}{l}\text { Categ } \\
\text { ory }\end{array}$ \\
\hline 1. & Validator 1 & 0.91 & Valid \\
2. & Validator 2 & 0.84 & Valid \\
& Average & 0.87 & Valid \\
\hline
\end{tabular}

Based on Table 4 shows the validation results of media experts on the e-module. The validation results show that this e-module has a validity value of $0.91 \geq 0.66$ given by the 1 st validator, the validity value of $0.84 \geq 0.66$ given by the 2 nd validator, so the e-module is included in the category valid.
Material Expert Validation

The results of the validation recapitulation are summarized from the aspects of the assessed e-module material as shown in table 5.

Table 5. Material Validation Data against E-module

\begin{tabular}{clll}
\hline No. & Validator & Assessment & Category \\
\hline 1 & Validator 1 & 0.86 & Valid \\
2 & Validator 2 & 0.84 & Valid \\
& Average & 0.85 & Valid \\
\hline
\end{tabular}

Based on table 5 above shows the results of the validation of the e-module has a validity value of $0.86 \geq 0.66$ given by the 1 st validator, the validity value of $0.85 \geq 0.66$ given by the 2 nd validator, then the material on the e-module is included in the valid category.

\section{Development Trial}

Practicality Test

Based on table 6, the e-module practicality value of the teacher's response can be averaged by $85.83 \%$, so it can be concluded that the media is included in the "Very Practical" category. So that the representation of these data shows that the use of e-modules really helps teachers in carrying out the learning process.

Table 6. Practicality Test Data Based on Teacher Responses

\begin{tabular}{cclc}
\hline No. & $\begin{array}{c}\text { Assessment } \\
\text { Aspects }\end{array}$ & Average value & Category \\
\hline 1 & Learning & $87.5 \%$ & Very Practical \\
2 & Theory & $80 \%$ & Very Practical \\
3 & Design & $90 \%$ & Very Practical \\
& Average & $85.83 \%$ & Very Practical \\
\hline
\end{tabular}

Based on table 7, the average value of e-module practicality from student responses is $84.67 \%$. So it can be concluded that the e-module is included in the "Very Practical" category. So that the representation of these data shows that the use of e-modules really helps students in carrying out the learning process.

Table 7. Practicality Test Data Based on Student Responses

\begin{tabular}{cccc}
\hline No. & Assessment Aspects & $\begin{array}{c}\text { Per } \\
\text { percentage } \\
(\%)\end{array}$ & Category \\
\hline 1 & Learning & $82.21 \%$ & Very Practical \\
2 & Display & $83.59 \%$ & Very Practical \\
3 & Programming & $88.24 \%$ & Very practical \\
& Average Practicality & $84.67 \%$ & Very Practical \\
& ReStudent sponge & & \\
\hline
\end{tabular}


Effectiveness Test

Based on table 8, the pretest results with a total of 34 students, there were 7 students who passed and 27 students who did not pass, while in the post-test there were 30 students who passed and 4 students who did not pass.

Table 8. Student Learning Outcomes of Pretest and

\begin{tabular}{|c|c|c|c|c|c|c|}
\hline \multirow{2}{*}{ No. } & \multirow{2}{*}{ Act } & \multirow{2}{*}{$\begin{array}{c}\text { Total } \\
\text { students }\end{array}$} & \multicolumn{2}{|c|}{$\begin{array}{l}\text { Learning } \\
\text { outcomes }\end{array}$} & \multicolumn{2}{|c|}{ Percentage } \\
\hline & & & $\begin{array}{c}\text { Gradu } \\
\text { ated }\end{array}$ & $\begin{array}{l}\text { Not } \\
\text { pass }\end{array}$ & $\begin{array}{c}\text { Graduate } \\
\text { d }\end{array}$ & $\begin{array}{l}\text { Not } \\
\text { pass }\end{array}$ \\
\hline 1 & Pretest & 34 & 7 & 27 & $20.59 \%$ & $\begin{array}{r}79.4 \\
1 \%\end{array}$ \\
\hline 2 & Posttest & 34 & 30 & 4 & $88.24 \%$ & $\begin{array}{l}11.7 \\
6 \%\end{array}$ \\
\hline
\end{tabular}

Classical completeness is seen from the percentage of students who completed the emodule. Based on The results of the analysis obtained data on the number of students who completed as many as 30 students $(88.24 \%)$, this shows that classical completeness has been achieved, it can be concluded that e-module is effective when viewed from classical completeness.

Enhancement Student learning outcomes after the pretest and post test were calculated with the gain score. Website-based learning module is said to be effective if the gain score is $\geq 0.3$ or at least in the medium category. The gain score obtained is 0.57 which is in the medium category.

\section{Dissemination Stage}

At this stage the e-module can be used by teachers and students in learning. Emodules that are ready can be distributed or used by other classes that have the same subjects such as the TAV (Audio Visual Engineering) department or other classes with the same vocational level. This dissemination stage is carried out with the aim of knowing the feasibility of using e-module learning by teachers and students, so that e-modules can be used by schools as a supporting tool that can be used to increase student motivation and learning effectiveness through quality learning.

\section{Implementation of Web Based Learning Module}

The process of developing this e-module starts from the process of preliminary analysis, design, and assessment. In the preliminary analysis stage, several activities were carried out, namely syllabus analysis, concept analysis, and analysis of student characteristics. This stage is carried out as a basis for developing e-modules on the subject of Computer Systems so that they can be used to facilitate students in understanding the material. After carrying out the preliminary analysis stage, an e-module is obtained which is used for basic competencies in understanding computer organization and architecture and the presentation of computer system structures.

This basic competency is divided into several indicators, namely analyze basic, combined and sequential logic relations and assemble the basic, combined and sequential logic gate functions. This learning module will later be accessible using a computer or smart phone via an online web browser. This learning module contains material, practice questions, discussion forums, and learning videos. After the Website-based learning module is developed, then the validity, practicality, and effectiveness test are carried out on the Website-based learning module.

\section{Module Validity}

Media validation was carried out on three aspects, namely (1) media appearance, (1) ease of program, (3) module utilization. This validation was assessed by two validators, the data from the validators came from the validity questionnaire that each validator filled out and the discussion showed the e-module. The e-module media validator provides validation values of 0.91 and 0.84 which are declared valid.

The results of the validation of the learning module from the media aspect show that the module display is good, easy to operate and the module components are in accordance with the systematics of the Website module. Based on the results of the analyzed validation, it can be concluded that the learning module developed from the media aspect is valid and as 
expected. In accordance with the opinion of Dahiya [7] where the digital module must consider the quality and quantity of media display, so that it is easy to read.

\section{Material Validation}

Material validation was carried out on three aspects, namely (1) suitability of material content, (2) learning, (3) summary. This validation was assessed by two validators. The mean results of the validation of the material were 0.86 and 0.84 in the valid category. The results of the validation of the learning module in the material aspect show that the material in the learning module is in accordance with the learning outcomes, the content of the material is clear and the summary is displayed correctly. Based on the validation results that have been analyzed, it can be concluded that the learning module is valid from the material aspect.

This is in line with the results of research by Neo which states that interactive modules are suitable for use as learning tools when viewed from the aspect of the suitability of the material in accordance with the learning objectives, updated concepts, and presentation systematics [8].

\section{Practicality Module}

This practicality test was carried out to reveal the readability of the learning module by teachers and students, how easy it was to use the learning module and student interest in the learning module. The average percentage of the results of the practicality questionnaire analysis from the teacher's point of view is $85.83 \%$ which is very practical. The average percentage of the results of the practicality questionnaire analysis from the point of view of students is $84.67 \%$ which is very practical. Purwanto says that a product is said to be practical if the target of achieving practicality is more than $75 \%$ [9].

Based on the results of the questionnaire analysis conducted with students and teachers, it can be concluded that the learning modules designed in this study can be read and understood clearly by students and teachers, are easy to use, and that students are interested in the modules used. From the explanation above it can be concluded that the
Website-based learning module is said to be practical.

\section{Module Effectiveness}

The effectiveness of developing this Website-based learning module can be seen in the subject of Computer Systems, especially in the basic competencies of explaining computer organization and architecture and presenting images of computer system structures carried out by conducting pre-test and post-test. Based on the results of the post-test given to class $\mathrm{X}$ students of the TKJ (computer and network engineering) expertise program, it was found that the completeness of the learning outcomes of students who reached the KKM (minimum completeness criteria) was $88.24 \%$, and by comparing the pretest and post-test scores the gain score was 0.57 in the moderate category. It can be concluded that this e-module is a learning module that is effective in using Computer Systems subjects.

\section{CONCLUSION}

Based on the results of research for the development of e-modules that have been carried out, the following conclusions are obtained:

1. From the development process carried out from the analysis stage to testing, this research has produced an e-module product for computer system subjects at SMK Negeri 1 Painan using the domain, namely https://emodulsiskom.com/smkn1painan/ which can be accessed by teachers and students. with a computer, laptop, or smartphone connected to the internet via a web browser whenever and wherever they are.

2. E-modules produced by experts as valid media so that they can be used as learning media, with an average media validity of 0.87 and material validity of 0.85 .

3. The e-module produced was also stated as a practical medium that was responded to by teachers and students, with a practicality value of teacher responses of $85.83 \%$ and student responses of $84.68 \%$.

The resulting e-module is also effective in increasing learning activities so that it has an impact on increasing student learning effectiveness by obtaining posttest results that meet the classical 
completeness criteria $88.24 \%$ with a gain score of 0.57 in the moderate category.

\section{SUGGESTION}

Based on the research conducted, the following requests are requested:

1. It is recommended to students, to be able to take advantage of this developed module as a module that can be used to improve understanding of the material and increase motivation and learning outcomes.

2. It is suggested to the teacher to be able to take advantage of this developed e-module, with the aim of increasing student motivation and learning outcomes.

\section{REFERENCES}

[1] M. Yandra and N. M. Sari, "Development of EModules Based on Project Based Learning Model for Highway and Bridge Construction Subject at Vocational High Schools," Proc. 1st Prog. Soc. ..., 2020, [Online]. Available: https://www.atlantis-

press.com/article/125943572.pdf.

[2] N. A. Nugraheni, R. M. Sugandi, and ..., "Learning Innovation for the Implementation of Industrial Practices for Construction Engineering and Property in Vocational High School According to the Construction ...," Teknol. dan Kejuru. ..., 2020, [Online]. Available: http://journal2.um.ac.id/index.php/teknolo gi-kejuruan/article/view/17065.

[3] R. Arthur, R. N. Dwi, and L. Lenggogeni, "EModule of Cost Estimating Course in Building Construction Vocational Undergraduate Program Faculty of Engineering Universitas Negeri Jakarta," J. Ilmu Pendidik., 2020, [Online]. Available: http://journal2.um.ac.id/index.php/jip/arti cle/view/14096.

[4] D. Ratnawati, R. Martono, and R. Rabiman, "Pengembangan E-Modul Sistem Rem untuk Siswa Sekolah Menengah Kejuruan," J. Din. Vokasional ..., 2020, [Online]. Available: https://journal.uny.ac.id/index.php/dynami ka/article/view/30987.

[5] A. A. Pranata, W. S. G. Irianto, and ..., “... mobile-based e-modules integrate learning model vak (visual, auditory, kinesthetic) to foster self-reliance of learning basic programming on the students of Vocational ...," VOLT J. IIm. ..., 2018, [Online]. Available: http://jurnal.untirta.ac.id/index.php/VOLT /article/view/3581.

[6] K. Anshari, K. Rukun, and A. Huda, "KA Development of E-Module Mikrotik Training Information Technology Teacher in the Field of Computer Network Engineering," J. Educ. ..., 2019, [Online]. Available: https://journal.unnes.ac.id/sju/index.php/j ed/article/view/34380.

[7] A. D. Samala, B. R. Fajri, and F. Ranuharja, "Desain Dan Implementasi Media Pembelajaran Berbasis Mobile Learning Menggunakan Moodle Mobile App," J. Teknol. Inf. dan Pendidik., vol. 12, no. 2, pp. 13-19, 2019, doi: 10.24036/tip.v12i2.221.

[8] A. D. Samala, B. R. Fajri, F. Ranuharja, and R. Darni, "Pembelajaran Blended Learning Bagi Generasi Z Di Era 4.0," J. Teknol. Inf. dan Pendidik., vol. 13, no. 1, pp. 45-53, Mar. 2020, doi: 10.24036/tip.v13i1.260.

[9] I. Solikin, "Implementasi E-Modul pada Program Studi Manajemen Informatika Universitas Bina Darma Berbasis Web Mobile," J. RESTI (Rekayasa Sist. Dan Teknol. ..., 2018, [Online]. Available: http://jurnal.iaii.or.id/index.php/RESTI/art icle/view/393.

[10] I. W. Sumandya and ..., "Developing Vocation Based Mathematics EModule in Linear Program Material," Int. J. ..., 2020, [Online]. Available:

http://repo.mahadewa.ac.id/id/eprint/102 $6 /$.

[11] P. Wahyuni, S. Haryani, and J. Jumaeri, "Design of Integrated Corrosion E-module Vocational Context to Improve Critical Thinking Skills of Class $\mathrm{X}$ Students in Vocational High School," Int. J. Act. ..., 2020, [Online]. Available: https://www.learntechlib.org/p/218511/.

[12] W. Wagiran, D. Rahdiyanta, A. E. Wibowo, and ..., "Online learning of mechanical engineering subject in the Covid-19 era: strategy, platform and media," J. Phys. ..., 2020, doi: 10.1088/17426596/1700/1/012027.

[13] B. D. D. Arianti and R. H. Wirasasmita, "WILMO (Web-based Interactive Learning Module), e-learning design for vocational school," J. Phys. Conf. ..., 2020, doi: 
10.1088/1742-6596/1539/1/012045.

[14] B. Haryadi and D. Widjanarko, "The Development of Sanggul Gala E-Modul at Beauty Study Program of Vocational High School," ... Vocat. Career Educ., 2021, [Online]. Available: https://journal.unnes.ac.id/nju/index.php/j vce/article/view/34901.

[15] A. S. Arief, "Pengembangan e-modul interaktif pada mata pelajaran Pemrograman Web untuk siswa kelas X TKJ SMK Negeri 1 Bangil," SKRIPSI Mhs. UM, 2021, [Online]. Available: http://mulok.library.um.ac.id/index3.php/8 1533.html. 